\title{
Earnings Forecasts Errors in Malaysian IPO Prospectuses: Evidence and Explanations
}

\author{
Mohammed Abdullah Ammer ${ }^{1}$ \& Nurwati A. Ahmad-Zaluki ${ }^{2}$ \\ ${ }^{1}$ Faculty of Commerce and Economics, Amran University, Yemen and Othman Yeop Abdullah Graduate School \\ of Business, University Utara Malaysia, Malaysia \\ ${ }^{2}$ Othman Yeop Abdullah Graduate School of Business, University Utara Malaysia, Malaysia \\ Correspondence: Mohammed Abdullah Ammer, Faculty of Commerce and Economics, Amran University, \\ Yemen and Othman Yeop Abdullah Graduate School of Business, University Utara Malaysia, Malaysia. E-mail: \\ mohd7776@yahoo.com.
}

Received: August 30, 2014 Accepted: October 20, 2014 Online Published: December 30, 2014

doi:10.5539/ass.v11n3p68 URL: http://dx.doi.org/10.5539/ass.v11n3p68

\begin{abstract}
This paper seeks to answer the questions concerning the current level of bias and accuracy associated with the IPO earnings forecasts and the explanations behind forecasts errors. Using 190 Malaysian IPOs, we found that the Malaysian IPO earnings forecasts during the period of study (2002-2012) were pessimistic (i.e., the earnings forecasts were underestimated), proposing that Malaysian IPO directors are, averagely unbiased and cautious forecasters. Moreover, we found the percentage of accuracy of Malaysian IPO earnings forecasts to be unsatisfactory. However, the percentage shows some improvement for the accuracy of earnings forecasts over time. Further, content analysis was used to explore the explanations provided behind the forecasts errors. This study found that, the number of provided explanations in first published annual report of IPO company was greater when the management of IPO companies were more optimistic in making their earnings forecasts (i.e., the earnings forecasts were over-forecasted) and when the forecasts errors were large. These results have implications for the capital market participants like regulators and investors.
\end{abstract}

Keywords: earnings, forecasts errors, prospectus, IPOs, Malaysia

\section{Introduction}

Equity IPOs are considered important in Malaysia. The government, in line with its New Economic Policy (NEP), can use it to redistribute wealth among ethnic groups and to increase Bumiputera ownership in the corporate sector (30\% by the end of 1990 from 2.4\% in 1971) (Koon, 1997). Under this Policy (NEP, 1971-1990, replaced by the National Development Policy (NDP) in 1991), IPO companies must reserve $30 \%$ of the shares of the public for Bumiputera applicants. IPO is also a means of raising funds and for ownership diversification. This importance provides the basis for more research into IPOs in Malaysia. In this regard, for a company to go public, the prospectuses are an important legal document. These prospectuses are used by IPO companies all over the world to publish financial forecasts (i.e., earnings, sales, expenses) according to their trust in the accuracy of these forecasts.

This present study focuses on the earnings forecasts, which is one of the most significant information related to IPOs (Chen \& Firth, 1999).Companies that are externally raising capital for the first time in public markets face great information asymmetry between the current shareholders and expected investors (Guo et al., 2004; Chong \& Ho, 2007; Bédard et al., 2008). Earnings forecasts can mitigate information asymmetries and illustrate the financial position of IPO companies to the potential investors (Gounopoulos, 2011). However, a significant over-forecasting of the management earnings forecast could result in misguiding the investors and other users like financial analysts. Therefore, the reliability of earnings forecast included in IPO prospectuses has been a main concern to market participants and the policy makers of capital markets whether in Malaysian IPO market or elsewhere (El-Rajabi \& Gunasekaran, 2006; Mnif, 2010; Ammer \& Ahmad-Zaluki, 2014).

The objective of our study is twofold. First, this paper aims to explore the current level of IPO earnings forecasts quality by investigating the accuracy and bias associated with these IPO forecasts. Second, it aims to determine the explanations that have been provided in the first published annual reports by the management when the 
earnings forecasts made in their IPO prospectuses have deviated outside $\pm 10 \%$ tolerated by the Securities Commission (SC).The motivation to conduct this study lies in the increasing number of newly established companies that went public in Malaysia and absorbed vast capital. This is evidenced by the increased number of listed companies on the Bursa Malaysia, from 285 companies at the beginning of 1990, to 941 companies at the end of 2011. In spite of these great developments in the IPOs market, studies on 'going public' in Malaysia are still somewhat limited.

This paper contributes to the management earnings forecasts and IPO literature. More importantly, there is a lack of prior studies related to investigating IPO earnings forecasts (Gounopoulos, 2011). Furthermore, the issue of explanations provided by directors in the first annual report after IPO has not been extensively investigated in the available literature. To date, only Lee et al. (1993) and Sweeting (2001) investigated the explanations of forecast errors. In addition, previous studies on Malaysian IPO management earnings forecasts did not address or consider this issue. Thus, by conducting this study we strive to fill these gaps in literature.

This study uses a sample of 190 IPO companies throughout the periods from 2002 to 2012.To achieve the objectives of this study, we used descriptive statistics and content analysis. In terms of earnings forecasts bias, this study found the Malaysian IPO earnings forecasts to be pessimistic. In regards of accuracy, the findings revealed that the Malaysian IPO earnings are unsatisfactory in terms of their accuracy level although it promises some improvement in the future. As for the explanations behind the forecasts errors, the study found that the number of explanations in first published annual report of IPO companies is higher when IPO companies management perceived optimism when making forecasts and when such forecasts errors were large.

The general implication of this study appears from the probability that the findings can support investors with their future evaluation concerning the quality of IPO earnings forecasts. Further, findings from this study might be valued input for the policy makers to plan and undertake the policies that are most suited for Malaysian IPOs market.

The remainder of our study is structured as follows. The next section presents and reviews the relevant literature. Then, the sections that follow provide an overview of the utilized research methods, results of descriptive and content analysis, and the conclusion of this study.

\section{Literature Review}

IPO earnings forecasts have received attention from researchers in several countries due to its importance in the investor's decisions (e.g., Henry et al., 2002; Hussin et al., 2004), IPO company valuation (e.g., Jelic et al., 1998; Chen \& Firth, 1999; Keasey \& McGuinness, 2008; Jelic, 2011) and security prices (e.g., Gounopolos, 2011).

In East Asian countries, the errors related to IPO earnings forecasts have been examined in several studies. For example, in Hong Kong, Jaggi (1997) revealed that unlike IPO earnings forecasts issued in many other countries, the Hong Kong IPOs managements did not over-forecast their earnings since they were conservative in issuing forecasts information by reporting forecast error of $6.5 \%$ and absolute forecasts error of $12.79 \%$. In addition, McGuinness (2005) found that the mean absolute earnings forecast error was about $7.26 \%$ for Hong Kong IPOs earnings forecasts during 2002-2003. McGuinness' results appear at a lower level of errors than what was reported in previous studies in Hong Kong (e.g., Jaggi, 1997). In China, Sun and Liu (2009) reported that while an average forecast error of Chinese IPO is $0.45 \%$, the absolute forecast error is $15.28 \%$. Their findings show improvement in Chinese IPO forecasts compared to those by Chen and Firth (1999) who showed that the average forecast error is $23.24 \%$ and the absolute forecast error is $43.09 \%$.In Singapore, Firth et al. (1995) investigated 114 Singaporean IPOs over the years from 1980 to 1993 . They reported that the average IPO earnings forecast error is $20.11 \%$, while the mean of absolute forecast error is $10.4 \%$. Their results showed that the IPOs of Singaporean companies had relatively great forecast accuracy. Finally, in Malaysia, 65 Malaysian IPOs were investigated by Mohamad et al. (1994) over the years from 1975 to 1988. Their findings showed that the average forecast error is about 9.34\%. Furthermore, Jelic et al. (1998) reported that earnings forecasts are under-forecasted on average by $33.37 \%$ and the mean absolute forecast error is $54.91 \%$. Their study is consistent with Mohamad et al.'s (1994) although it proposes smaller credibility. Further, Ahmad-Zaluki and Wan-Hussin (2010) indicated that the mean forecast error is $-3.50 \%$ and the mean absolute forecast error is $23.76 \%$. They attributed this result of over-forecasting in earnings to the economic conditions of their utilized sample period (1999-2006), which represents the time of recovery of the economic crisis experienced in 1997 and 1998.

In non-East Asian countries, Henry et al. (2002) found that the mean earnings forecast errors of Australian IPOs is around $-13.20 \%$ but on the other hand, Firth et al. (2012) revealed that the mean forecast error in Australia is $1.11 \%$. In New Zealand, the study of Firth and Smith (1992) indicated that the mean earnings forecast error of IPOs is about $-92 \%$, suggesting that these disclosed forecasts are considered excessively optimistic. In a related 
study, Pedwell et al. (1994) examined 112 Canadian IPOs during the period from 1983 to 1987 . Their results showed that IPO forecasts, typically surpass the actual earnings with the average absolute forecast error of $88 \%$, and mean forecast errors of $-77.7 \%$. Finally, for the French IPO market, Mnif (2010) reported that the average of forecast error is $-13.85 \%$. His result showed that French IPO companies slightly report optimistic earnings.

With regards to the explanations of earnings forecasts errors, Lee et al. (1993) and Sweeting (2001) indicated that IPO companies usually tend to provide explanations for their forecast errors when the error is both large and optimistic.

\section{Research Methods}

\subsection{Sample Selection}

This study used data collected from the prospectuses and annual reports of IPOs listed on the main market of Bursa Malaysia. We employed a sample of newly formed companies in the period from 2002 to 2012. The total IPOs during this period is 265. However, following Ahmad-Zaluki and Wan-Hussin (2010) we excluded the IPO companies in finance, real estate investment trust, infrastructure project, and close-end fund sectors owing to their dissimilar regulatory requirements. Furthermore, the IPOs that did not issue earnings forecasts in the prospectus are excluded from the final sample. Table 1 shows the procedure to arrive at the final sample comprising 190 IPOs.

Table 1. Derivation of sample

\begin{tabular}{cc}
\hline Sample Selection from 2002-2012 & \\
Total number of companies & 265 \\
less & 54 \\
Companies that did not disclose earnings forecasts & 4 \\
Financial related companies & 14 \\
Real estate investment trusts related companies & 1 \\
Closed-end funds related companies & 2 \\
Infrastructure related companies & 190 \\
\hline Final sample & \\
\hline
\end{tabular}

\subsection{Forecast Error Metrics}

Following previous studies (e.g., Firth \& Smith, 1992; Jelic et al., 1998; El-Rajabi \& Gunasekaran, 2006; Ahmad-Zaluki \& Wan-Hussin, 2010), we calculated the bias and accuracy of IPO earnings forecasts by using the following metrics.

$$
\begin{gathered}
F E R_{i t}=\left(A E_{i t}-F E_{i t}\right) /\left|F E_{i t}\right| \\
\operatorname{AFER}_{\mathrm{it}}=\left|\left(\mathrm{AE}_{\mathrm{it}}-\mathrm{FE}_{\mathrm{it}}\right)\right| /\left|\mathrm{FE}_{\mathrm{it}}\right|
\end{gathered}
$$

Where

$F E R_{i t} \quad=$ Forecast error (measuring the bias [pessimistic or optimistic]);

$A F E R_{i t} \quad=$ Absolute forecast error (measuring the level of accuracy);

$A E_{i t} \quad=$ Actual earnings of company $\mathrm{i}$ for the period $\mathrm{t}$;

$F E_{i t} \quad=$ Forecast earnings as given in the IPO prospectus of company $\mathrm{i}$ for the period $\mathrm{t}$.

\section{Results and Discussion}

\subsection{Descriptive Statistics}

The results reported in Table 2 indicate that the mean forecast error (FER) for the full sample is $3.36 \%$, which means that the Malaysian IPO earnings forecasts during the period of study were pessimistic. The positive sign for the mean forecast error indicates that the actual reported earnings in annual report surpass their forecasted 
earning in IPO prospectus. One sample t-test and Mann-Whitney test in Table 2 also indicate that the mean and median of FER is insignificantly not equal to zero ( $p$-value $=0.396 ; p$-value $=0.896)$ and its distribution is skewed to the left, which proves that most of the forecast errors are considered a pessimistic bias. While this study reports a positive mean of FER, the study of Ahmad-Zaluki and Wan-Hussin (2010) reported a negative optimistic FER with a negative mean of 3.50\%. Further, this finding of FER is less than the result documented in previous Malaysian studies (e.g., 9.34\% in Mohamad et al., 1994). Also, it disagrees with the international evidence evidencing that management of IPOs is usually over-optimistic in forecasting their earnings (i.e. the actual earnings reported in the annual report is less than the forecasted earnings in prospectus). For example, FER in Australia is $-30.35 \%$ as reported by Hartnett and Römcke (2000) and $-13.20 \%$ as reported by Henry et al. (2002), in New Zealand, it is $-91.00 \%$ by Firth (1997) and $-37.10 \%$ by Hsu et al. (2000), and finally, in France it is $-13.85 \%$ as reported by Mnif (2010).

Overall, the findings concerning the bias propose that Malaysian IPO directors are, averagely, unbiased and cautious forecasters indicating a general decrease in the forecast bias of Malaysian IPOs over time.

Table 2. Descriptive statistics of the accuracy and bias of management earnings forecasts

\begin{tabular}{lcc}
\hline & FER (\%) & AFER (\%) \\
\hline Full Sample (Jan 2002-Feb 2012) $(\mathrm{n}=190)$ & \\
\hline Mean & 3.36 & 24.94 \\
p-value & 0.396 & 0.000 \\
Median & 1.12 & 9.37 \\
p-value & 0.896 & 0.000 \\
Std. & 54.50 & 48.54 \\
Minimum & -176.04 & 0.13 \\
Maximum & 525.45 & 525.45 \\
\hline
\end{tabular}

Results significantly different from zero at the ${ }^{*} 0.05,{ }^{* *} 0.01$ and ${ }^{* * *} 0.001$ levels, respectively, using two-tailed tests.

Table 2 further shows that the mean and median of absolute forecast error (AFER) are $24.94 \%$ and 9.37\%, respectively. The results from t-test and Mann-Whitney test indicate that the mean and median of AFER are significantly greater than zero ( $p$-value $=0.000 ; p$-value $=0.000$ ). In relation to prior Malaysian studies, the mean AFER of this study is less than the AFER of $28.00 \%$ and $54.91 \%$ reported by Mohammed et al. (1994) and Jelic et al. (1998) respectively, but is similar to the reported AFER (23.76\%) in the study by Ahmad-Zaluki and Wan-Hussin (2010). Compared to prior international studies, AFER in this study is much less than those reported in Australia (e.g., 1138.30\% in Lee et al., 1993; 406.20\% in Chapple et al., 2005), in Jordon (e.g., $163.40 \%$ in El-Rajabi \& Gunasekaran, 2006), and it is also relatively smaller compared to the $37.50 \%$ by Gallery et al. (2011) in Australia and $42.82 \%$ by Gounopoulos (2003) in Greece. However, it is moderately higher than other AFER in U.K (e.g., $11.00 \%$ by Keasey \& McGuiness, 1991), China (e.g., 15.28\% by Sun \& Liu, 2009), Singapore (e.g., $10.40 \%$ by Firth, 1997), and Hong Kong (e.g., $18.00 \%$ by Chan et al., 1996; $21.96 \%$ by Chen et al., 2001).

As a result, this percentage of accuracy of Malaysian IPO earnings forecasts is not satisfactory. The mean of AFER should not be significantly different from zero. However, the mean of AFER in the present study shows some improvement for the accuracy of earnings forecasts over time. Nonetheless, comparing to countries such as UK, Singapore, and Hong Kong, the management of Malaysian IPO companies still needs to issue more accurate earnings forecasts.

Furthermore, Table 3 illustrates the summary statistics of IPO management earnings forecast accuracy measures through the period of study. It is clear that all the means of forecast error (FER) are positive except for the FER in 2002 and 2005, indicating that Malaysian IPO issued optimistic earnings forecasts during the year of 2002 and 2005. For example, in 2002, the averages of forecast errors and absolute forecast errors are considerably different from each other because of the over-forecasting of earnings in the prospectus by around $50 \%$ by Meda Inc. Berhad. The great difference shows that the disclosed earnings forecasts in 2002 are more optimistic than pessimistic.

For the accuracy, Table 3 indicates that the year of 2003 has the lowest level of earnings forecasts accuracy with a mean AFER of $43.23 \%$. On the other hand, the year of 2010 presents the highest level of accuracy with low levels of mean AFER (5.41\%). 
Table 3. Descriptive statistics of IPO earnings forecast accuracy (by cohort year)

\begin{tabular}{cccccccc}
\hline \multirow{2}{*}{ Year } & \multirow{2}{*}{ Forecasting IPOs } & \multicolumn{3}{c}{ FER (\%) } & \multicolumn{3}{c}{ AFER (\%) } \\
\cline { 2 - 7 } & & Mean & Median & Std. & Mean & Median & Std. \\
\hline 2002 & 43 & -0.73 & 0.73 & 25.29 & 13.67 & 6.87 & 21.18 \\
2003 & 36 & 8.87 & 2.09 & 101.62 & 43.23 & 15.06 & 92.11 \\
2004 & 41 & 2.91 & -2.74 & 53.70 & 28.97 & 9.43 & 45.08 \\
2005 & 26 & -5.72 & -5.75 & 34.13 & 25.41 & 18.50 & 22.96 \\
2006 & 14 & 6.12 & 6.18 & 9.76 & 8.98 & 7.04 & 6.98 \\
2007 & 19 & 11.33 & 5 & 24.76 & 17.95 & 8.46 & 20.22 \\
2008 & 10 & 7.36 & 8.59 & 34.82 & 27.28 & 22.74 & 21.11 \\
2009 & 0 & - & - & - & - & - & - \\
2010 & 1 & 5.41 & 5.41 & 0.00 & 5.41 & 5.41 & 0.00 \\
2011 & 0 & - & - & - & - & - & - \\
2012 & 0 & - & - & - & - & - & - \\
\hline All & 190 & 3.36 & 1.12 & 54.50 & 24.94 & 9.37 & 48.54 \\
\hline
\end{tabular}

\subsection{Content Analysis}

As highlighted earlier, the objective of our study is also to explore the explanations that have been disclosed by the management in the first published annual reports when the earnings forecasts errors are more than $\pm 10 \%$. To achieve this objective, analysis is done manually employing content analysis as described in the following sections.

\subsubsection{Analysis of Provided General Comments}

In order to obtain these explanations, the first published annual reports by IPO companies were explored. The directors' comments and explanations on the errors of management earnings forecasts are commonly stated in the Chairman's statement and under the additional notes on financial statements. In Panel A of Table 4, it is obvious that 163 IPO companies $(85.79 \%)$ out of the total sample of this study (190 IPOs) generally provided an explicit reference concerning earnings forecasts in their annual reports regardless of whether or not they were included to explain errors. The provided comments are specifically related to the performance of actual earnings compared to earnings forecasts.

Table 4. Provided comments on earnings forecasts errors in annual reports

\begin{tabular}{|c|c|c|c|}
\hline \multicolumn{4}{|l|}{ Panel A: Number of Provide Comments } \\
\hline Comments & Number of IPO & \multicolumn{2}{|c|}{$\%$} \\
\hline Yes & 163 & \multicolumn{2}{|c|}{85.79} \\
\hline No & 27 & \multicolumn{2}{|c|}{14.21} \\
\hline Total & 190 & \multicolumn{2}{|c|}{100} \\
\hline \multicolumn{4}{|c|}{ Panel B: Directors' Comments on Actual Earnings Compared to Forecasted Earnings } \\
\hline Comments & Number of IPO & \multicolumn{2}{|c|}{$\%$} \\
\hline AE higher than FE (difference $>+10$ ) & 37 & \multicolumn{2}{|c|}{22.70} \\
\hline $\mathrm{AE} \quad$ less than $\mathrm{FE}($ difference $<-10)$ & 42 & \multicolumn{2}{|c|}{25.77} \\
\hline $\mathrm{AE}$ in line with $\mathrm{FE}(-10<$ difference $<+10)$ & 84 & \multicolumn{2}{|c|}{51.53} \\
\hline Total & 163 & \multicolumn{2}{|c|}{100} \\
\hline \multicolumn{4}{|l|}{ Panel C: Explanations of Forecast Errors } \\
\hline Explanations & \multicolumn{3}{|c|}{ Number of IPO \% } \\
\hline \multirow{4}{*}{$\begin{array}{l}\text { when } \mathrm{AE} \text { is higher than } \mathrm{FE} \\
\text { when } \mathrm{AE} \text { is below } \mathrm{FE}\end{array}$} & Yes & No & Total \\
\hline & 44 & 61 & 105 \\
\hline & 40 & 45 & 85 \\
\hline & 84 & 106 & 190 \\
\hline
\end{tabular}

Note: AE is the actual earnings provided in the first issued annual report. FE is the forecasted earnings disclosed in the IPO prospectus.

Panel B of Table 4 classified the comments on forecasts that compared with actual earnings into three groups. The first group represents the comments on forecasts errors when the difference between actual reported 
earnings and forecasted earnings in IPO prospectus is higher than the tolerance level of $+10 \%$ stated by SC. This group includes $22.70 \%$ ( 37 IPO companies). On the other hand, the second group represents the comments on forecasts errors when the difference between actual reported earnings and forecasted earnings in IPO prospectus is lower than the tolerance level of $-10 \%$. This group comprises $25.77 \%$ (42 IPOs) out of 163 IPOs that provided comments.

It can be noted that, the number of provided comments is higher when the management of IPO companies are more optimistic (when the difference between actual earnings and the forecasts is negative). It is of great significance to tell the investors why this negative deviation happened not just to fulfill the requirements of SC but also to maintain investments in the company and to increase the confidence in capital market in general. Interestingly, most comments are provided when the forecast errors are in line with the tolerance level of \pm 10 . This group includes 84 IPOs out of total 163 IPO companies that provided comments in their first issued annual reports. This may be attributed to the IPO directors' interest in informing the related parties that their forecasts are, to some extent, accurate. These explanations potentially aid investors in understanding the situation of IPO company.

\subsubsection{Analysis of Provided Explanations}

Out of 190 IPOs sample utilized in this study, the search through annual reports following IPOs yielded only 84 IPOs that explained the reasons behind the deviations reported on forecasts errors. Panel C of Table 4 considers the explanations provided by management for the forecasts errors. The results in Table 4 show that under-forecasting IPOs comprise $52.38 \%$ of all provided explanations (44 out of 84 ) and represent $55.26 \%$ of the total sample (105 out of 190). On the other hand, the over-forecasting IPOs represent $47.62 \%$ (40 out of 84 ) of all explainer IPOs. It can be noted that, directors of Malaysian IPO provided more explanations for forecasts errors when actual earnings did not exceed forecasted earnings since the percentage of provided explanations for optimistic forecasts is $47.06 \%$ (40 out of 85 IPOs), which is higher than $40.90 \%$ (44 out of 105 IPOs) for pessimistic forecasts.

This result is consistent with Lee et al. (1993) and Sweeting (2001) who revealed that IPO companies are typically inclined to issue explanations for their forecast errors when the error is both large and optimistic. However, the explanations that were provided when the actual earnings exceeded the forecasts earnings are few and general compared with a higher number of general and specific explanations, were provided when actual earnings were lower than forecasts earnings.

To confirm the above results, Table 5 provides the relationship between the bias (as represented by FER) and accuracy (as represented by AFER) of earnings forecasts and the explanations provided for them. When comparing the results under explanations with no explanations, the findings indicate that the explanations, on average, were provided when the forecast errors were large, less accurate and optimistic.

Table 5. Explanations and forecast bias and accuracy measures

\begin{tabular}{lccc}
\hline Measurement & Explainers & Non-explainers & Total \\
& $\mathrm{N}=84$ & $\mathrm{~N}=106$ & $\mathrm{~N}=190$ \\
& Mean $(\%)$ & Mean $(\%)$ & Mean $(\%)$ \\
\hline FER & -5.06 & 10.03 & 3.36 \\
AFER & 27.19 & 23.14 & 24.94 \\
\hline
\end{tabular}

Note: Forecast Error $(\mathrm{FER})=\left(\mathrm{AE}_{\mathrm{it}}-\mathrm{FE}_{\mathrm{it}}\right) /\left|\mathrm{FE}_{\mathrm{it}}\right|$. Absolute Forecast Error $(\mathrm{AFER})=\left|\left(\mathrm{AE}_{\mathrm{it}}-\mathrm{FE}_{\mathrm{it}}\right)\right| /\left|\mathrm{FE}_{\mathrm{it}}\right| . \mathrm{AE}^{\mathrm{A}}$ is the actual earnings in annual report by the IPO company; and EF, is the disclosed forecasted earnings in the IPO prospectus.

\subsubsection{Explanations- Actual Earnings Higher than Forecasts Earnings}

The results in Table 6 present the explanations provided by directors when the forecasts errors are pessimistic (actual earnings higher than forecasts earnings). These explanations were classified into seven groups by gathering the similar explanations in one specific group. Table 6 presents a summary of the seven explanatory groups in addition to the number of IPO companies that offered each kind of explanations.

As highlighted earlier, the provided reasons on these occasions tend to be limited and general. The groups of increased demand/sales, increased price, and lower cost/expense are the three popular explanations for the pessimistic IPO management. The most provided explanation (26 times) is concerning the increased demand and sales, which leads to increased revenue. 
Table 6. Classifications of explanations offered when actual earnings are higher than forecasts earnings

\begin{tabular}{llc}
\hline NO & Type of Explanations & No. of IPO Companies \\
\hline 1 & Increased demand/sales & 26 \\
2 & Increased price & 6 \\
3 & Lower cost/expense & 8 \\
4 & Improved economic activities & 1 \\
5 & Write-up of intangible assets (i.e., goodwill, trademarks, research and development). & 2 \\
6 & Gain on exchange rate & 2 \\
7 & Others (i.e., tax saving, disposal of some assets, and lower bad debt charges) & 9 \\
\hline
\end{tabular}

\subsubsection{Explanations- Actual Earnings Lower than Forecasts Earnings}

When the actual earnings is less than forecasts earnings, management provided a variety of explanations. Similar explanations were classified together into thirteen groups. Some of these categories and items were drawn from prior studies in the area (e.g., Lee et al., 1993: Sweeting, 2001). Table 7 lists these thirteen classified groups. While there were only forty IPOs that have explained the forecasts errors when actual earnings less than forecasted earnings (as noted previously in Panel C of Table 4), a total of 93 explanations were reported in annual reports. This is because many IPO companies released multiple explanations for the reported forecasts errors.

The most common provided explanations were the 'increase in the cost of raw material and materials shortage'. Under this category, directors mentioned that their companies faced a sharp increase in the cost of main raw material for the manufacturing operations specially the petroleum-based raw materials. The increase of oil prices positively increased the overall operating cost. Further, some IPO companies during the period of the study experienced materials shortage especially in the construction industry. The next top popular explanations group is 'unanticipated costs'. This explanation is to a certain degree unclear, since it would mean the costs were greater than anticipated or the IPO management failed to budget for these costs. In both occasions, part of responsibility is likely to be placed upon the IPO management. Perhaps the management did not carefully consider all matters during making earnings forecasts as well as they did not react well to unexpected events during the forecasting period to live up to the forecasted figures in IPO prospectus.

Another common explanation is 'lack of sales and demand'. Many directors attributed the shortfall of earnings to lower sales. While directors in these occasions were trying to relate this shortfall of sales to the reasons beyond their control, they had to carry some responsibility for that. Examples for their explanations are:

"Lower sales are a result of weak market conditions especially in Avian Flu scare has resulted in lower demand for chicken meat as consumers switched their consumption of chicken meat to other meat (D.B.E Gurney Resources Berhad, Annual Report 2004, p. 22".

"A decrease of approximately $10 \%$ in export sales to several customers in the Middle East countries was due to the region's political instability (Tafi Industries Berhad, Annual Report 2005, p. 13)".

Table 7. Classifications of explanations offered when actual earnings less than forecasts earnings

\begin{tabular}{|c|c|c|}
\hline NO & Type of Explanations & $\begin{array}{l}\text { No. of IPO } \\
\text { Companies }\end{array}$ \\
\hline 1 & Unanticipated costs (other than those determined separately) & 12 \\
\hline 2 & Delays in commencing operations/installation of new equipment/ acquisition of operating subsidiaries. & 11 \\
\hline 3 & Economic events/ interest rates. & 11 \\
\hline 4 & Predatory pricing/competition & 5 \\
\hline 5 & Lack of sales and demand & 13 \\
\hline 6 & Unfavorable weather conditions/floods & 1 \\
\hline 7 & Increase in the cost of raw material/ materials shortage & 21 \\
\hline 8 & Personnel shortage/resignation/ staff cost & 2 \\
\hline 9 & Government actions /financial and accounting policies & 1 \\
\hline 10 & Failures in entities acquired to meet budget profit levels / low profitability & 2 \\
\hline 11 & IPO financing problems/lack of working capital & 2 \\
\hline 12 & Exchange rate & 2 \\
\hline 13 & Others & 10 \\
\hline
\end{tabular}


Furthermore, results in Table 7 presents other explanations that directors refer to in case of negative forecasts errors. Explanations (e.g. delays in commencing operations/installation of new equipment/ acquisition of operating subsidiaries and economic events/ interest rates) have been reported many times by IPO management. The less indicated explanation was under the group nine (1 IPO) (government actions /financial and accounting policies). Specifically, CYL Corporation Berhad explained part of the shortfall of "RM819,038 due to the change in accounting policy for deferred tax, Annual Report 2004, p. 13".

Overall, it can be noted from the presented explanations in Table 7 that the management of IPO companies has tried to attribute most of explanations behind the forecasts errors to reasons outside their control; for example, delays in commencing operations, economic events, exchange rate, and government actions.

It is remarkable that the group of 'unfavorable weather conditions/floods' is most clearly not associated with the management performance, ability, and skills. Example for this group is:

"Thai AirAsia was not able to meet its profit forecast due to domestic competition and several unforeseen circumstances. The air travel sentiments were dampened by the unexpected Tsunami disaster, multiple earthquakes off Sumatra and unrest in southern Thailand that occurred in the 2nd and 3rd quarter of the financial year ended $30^{\text {th }}$ June 2005 (AirAsia Berhard, Annual Report 2005, p. 48)"

Finally, the group 'others' in Table 7 represents several of different explanations which cannot be classified with other similar explanations into other groups. Examples of this group are:

"Non-achievement of the profit forecast was primarily due to additional provision of doubtful debts of RM1.2 million which was in relation to a trading debt that occurred in 2005 (Tafi Industries Berhad, Annual Report 2005, p. 13)"'.

\section{Conclusions and Implications}

The main purpose of this study is to provide further empirical evidence on the current level of earnings forecasts quality of Malaysian IPOs by examining the level of related bias and accuracy with such earnings forecasts. Further, this study aims to explore the explanations behind the forecasts errors of earnings. This empirical study found that the mean forecast error was positive, which indicates that earnings forecasts of Malaysian IPO were pessimistic. This result is inconsistent with the evidence of other studies dedicated to the same context stating that management of IPOs generally issue more optimistic earnings forecasts. For the accuracy of earnings forecasts included in IPO prospectus, the study reports low mean of accuracy, which means that Malaysian IPO companies issue accurate earnings forecasts to some extent, but they are still unsatisfactory.

In terms of explanations of forecasts errors, we found that the explanations are provided commonly for optimistic and large forecasts errors. Further, it was reported that the explanations were provided when the forecasts errors are negative, showing that the reasons behind the deviations of forecasts were related to situations and events that were outside the control of IPO management. Therefore, the responsibility cannot be placed on IPO management.

The present study's general implications arise from the findings potential to support investors in their evaluations of IPO earnings forecasts in terms of quality. The study findings may also serve as an invaluable input for policy makers in their planning and establishing policies that are appropriate for the IPO market in Malaysia.

Further, the implication of the results entails that, further effort should be carried out by the management of future Malaysian IPOs in order to enhance the accuracy of earnings forecasts. Furthermore, Malaysian IPO management should be more careful in conducting earnings forecasts and in considering factors as indicated by Chan et al. (1996) and Jelic et al. (1998). They showed that accurate earnings forecasts are a result of the absence of difficulty of forecasting (e.g., the underlying variability and instabilities of business circumstances), the proficiency of the managers undertaking the earnings forecasts, and the capability and readiness of company management to 'manage' their earnings.

\section{References}

Ahmad-Zaluki, N. A., \& Wan-Hussin, W. N. (2010). Corporate governance and earnings forecasts accuracy. Asian Review of Accounting, 18(1), 50-67. http://dx.doi.org/10.1108/13217341011046006

Ammer, M. A., \& Ahmad-Zaluki, N. A. (2014). Absolute forecast errors of earnings in Malaysian IPO prospectuses: The impact of ethnic diversity. Jurnal Teknologi, 68(3), 97-104. http://dx.doi.org/10.11113/jt.v68.2954

Bédard, J., Coulombe, D., \& Courteau, L. (2008). Audit committee, underpricing of IPOs, and accuracy of management earnings forecasts. Corporate Governance: An International Review, 16(6), 519-535. 
http://dx.doi.org/10.1111/j.1467-8683.2008.00708.x

Chan, A. M., Sit, C. L. K., Tong, M. M. L., Wong, D. C. K., \& Chan, R. W. Y. (1996). Possible factors of the accuracy of prospectus earnings forecast in Hong Kong. International Journal of Accounting, 31(3), 381-398. http://dx.doi.org/10.1016/S0020-7063(96)90026-6

Chapple, L., Clarkson, P., \& Peters, C. (2005). Impact of the corporate law economic reform program act 1999 on initial public offering prospectus earnings forecasts. Accounting and Finance, 45(1), 67-94. http://dx.doi.org/10.1111/j.1467-629x.2004.00123.x

Chen, G., \& Firth, M. (1999). The accuracy of profit forecasts and their roles and associations with IPO firm valuations. Journal of International Financial Management \& Accounting, 10(3), 202-226. http://dx.doi.org/10.1111/1467-646X.00051

Chen, G., Firth, M., \& Krishnan, G. V. (2001). Earnings forecast errors in IPO prospectuses and their associations with initial stock returns. Journal of Multinational Financial Management, 11(2), 225-240. http://dx.doi.org/10.1016/S1042-444X(00)00051-7

Chong, B. S., \& Ho, K. W. (2007). Lockup and voluntary earnings forecast disclosure in IPOs. Financial Management, 36(3), 63-80. http://dx.doi.org/10.1111/j.1755-053X.2007.tb00081.x

El-Rajabi, M. T. A., \& Gunasekaran, A. (2006). The accuracy of earnings forecasts disclosed in the prospectuses of newly formed public companies in Jordan. Managerial Auditing Journal, 21(2), 117-131. http://dx.doi.org/10.1108/02686900610639275

Firth, M. (1997). An analysis of the stock market performance of new issues in New Zealand. Pacific-Basin Finance Journal, 5(1), 63-85. http://dx.doi.org/10.1016/S0927-538X(96)00026-1

Firth, M., \& Smith, A. (1992). The accuracy of profits forecasts in initial public offering prospectuses. Accounting and Business Research, 22(87), 239-247. http://dx.doi.org/10.1080/00014788.1992.9729441

Firth, M., Gounopoulos, D., \& Pulm, J. (2012). IFRS adoption and management earnings forecasts of Australian IPOs. Working paper, EFMA-University of Barcelona.

Firth, M., Kwok, C., \& Keng, L. T. C. (1995). Accuracy of profit forecasts contained in IPO prospectuses. Accounting and Business Review, 2(1), 55-83. http://dx.doi.org/10.1142/S0218556395000043

Gallery, G., Gallery, N., \& Linus, A. (2011). The impact of regulatory reforms on the earnings forecasting behavior of IPO firms. Pacific Accounting Review, 23(3), 286-315. http://dx.doi.org/10.1108/01140581111185517

Gounopoulos, D. (2003). Accuracy of management earning forecast in IPO prospectuses. Working paper. Retrieved from http://www.academia.edu/729840

Gounopoulos, D. (2011). Associations between management forecast accuracy and pricing of IPOs in Athens Stock Exchange. Multinational Finance Journal, 15(3-4), 235-272.

Guo, R. E. J. I. N., Lev, B., \& Zhou, N. (2004). Competitive costs of disclosure by biotech IPOs. Journal of Accounting Research, 42(2), 319-355. http://dx.doi.org/10.1111/j.1475-679X.2004.00140.x

Hartnett, N., \& Römcke, J. (2000). The predictability of management forecast error: A study of Australian IPO disclosures. Multinational Finance Journal, 4(1-2), 101-132.

Henry, D. J., Ahmed, K., \& Riddell, A. S. (2002). The effect of IPO prospectus earnings forecast errors on shareholder returns. Journal of Corporate Communications, 4, 1-26.

Hsu, W. E. N. H. S. I. L., Hay, D., \& Weil, S. (2000). Forecast accuracy and bias in IPO prospectuses: Recent New Zealand evidence. Pacific Accounting Review, 12(1), 27-59. http://dx.doi.org/10.1108/eb037948

Hussin, B. M., Sulong, F., \& Osman, S. (2004). The effect of forecast earnings errors in IPO prospectus on shareholders return. Paper presented at the International Business Management conference, Malaysia.

Jaggi, B. (1997). Accuracy of forecast information disclosed in the IPO prospectuses of Hong Kong companies. International Journal of Accounting, 32(3), 301-319. http://dx.doi.org/10.1016/S0020-7063(97)90013-3

Jelic, R. (2011). Management forecasts and IPO performance. Working paper. Retrieved from http://efmaefm.org/0efmsymposium/oxford-2008/jelic.pdf

Jelic, R., Saadouni, B., \& Briston, R. (1998). The accuracy of earnings forecasts in IPO prospectuses on the Kuala Lumpur Stock Exchange. Accounting and Business Research, 29(1), 57-72. 
http://dx.doi.org/10.1080/00014788.1998.9729566

Keasey, K., \& McGuinness, P. (1991). Prospectus earnings forecasts and the pricing of new issues on the unlisted securities market. Accounting and Business Research, 21(82), 133-145. http://dx.doi.org/10.1080/00014788. 1991.9729826

Keasey, K., \& McGuinness, P. B. (2008). Firm value and its relation to equity retention levels, forecast earnings disclosures and underpricing in initial public offerings in Hong Kong. International Business Review, 17(6), 642-662. http://dx.doi.org/10.1016/j.ibusrev.2008.09.002

Koon, H. (1997). The new economic policy and the Chinese community in Peninsular Malaysia. Developing Economies, 35(3), 262-292. http://dx.doi.org/10.1111/j.1746-1049.1997.tb00848.x

Lee, P., Taylor, S., Yee, C., \& Yee, M. (1993). Prospectus earnings forecasts: Evidence and explanations. Australian Accounting Review, 3(5), 21-32. http://dx.doi.org/10.1111/j.1835-2561.1993.tb00142.x

McGuinness, P. B. (2005). A re-examination of the disclosure of discretionary earnings forecasts: The case of initial public offerings in Hong Kong. SFC Quarterly Bulletin, Summer, 10-31.

Mnif, A. (2010). Corporate governance and management earnings forecast quality: Evidence from French IPOs. Retrieved from http://halshs.archives-ouvertes.fr/halshs-00459171/en/

Mohamad, S., Nassir, A., Kuing, T., \& Ariff, M. (1994). The accuracy of profit forecasts of Malaysian IPOs. Capital Markets Review, 2(2), 46-69.

Pedwell, K., Warsame, H., \& Neu, D. (1994). The accuracy of Canadian and New Zealand earnings forecasts: A comparison of voluntary versus compulsory disclosures. Journal of International Accounting, Auditing and Taxation, 3(2), 221-236. http://dx.doi.org/10.1016/1061-9518(94)90018-3

Sun, J., \& Liu, G. (2009). The impact of the CSRC regulation no. 12-1996 on the credibility of Chinese IPO earnings forecasts. Global Finance Journal, 20(2), 165-179. http://dx.doi.org/10.1016/j.gfj.2008.10.001

Sweeting, J. (2001). An analysis of forecast error associated with profit forecasts in Australian IPO prospectuses. Working paper. Retrieved from http://www.docin.com/p-95021744.html

\section{Copyrights}

Copyright for this article is retained by the author(s), with first publication rights granted to the journal.

This is an open-access article distributed under the terms and conditions of the Creative Commons Attribution license (http://creativecommons.org/licenses/by/3.0/). 